\title{
Analisis Praktik Wacana Mengenai Kelompok LGBT dalam Publikasi Daring Feminis
}

\author{
Anggita Ayu Indari, Dr. Wiwik Novianti, M.I.kom \\ Jurusan Ilmu Komunikasi Fakultas Ilmu Sosial dan Ilmu Politik \\ Universitas Jenderal Soedirman Purwokerto \\ anggitaindari@gmail.com
}

\begin{abstract}
Nowadays, the discourse of LGBT people in Indonesia's mainstream media is still so heteronormative and religious-bias. Contrarily to the fact, there is still a media that offers an alternative even though most of Indonesian Media only covers prominent discourse regarding to LGBT people. Magdalene is the example of one of them. Through their online publication, Magdalene tries to challenge the hegemony of mainstream media which often marginalizes, subordinates, and stigmatizes LGBT people. It is quite interesting because actually Magdalene is created as feminist publication which covers the voice of women, not particularly LGBT people.

This study aims to find out how the contents about LGBT people in Magdalene's online publication is influenced by the discourse practice of the media. In conducting the analysis, researcher uses the Discourse Practice Analysis based on Norman Fairclough's Critical Discourse Analysis. Additionally, the analysis is also based on Reese \& Shoemaker's Hierarchy of Influences on Media Content. In the end, the result shows that the discourse of LGBT people in Magdalene's online publication is significantly influenced by personal attitudes, beliefs, and values upheld by the editorial team.
\end{abstract}

Keywords: LGBT people, discourse practice analysis, online media, the hierarchy of Influences on media content.

\section{PENDAHULUAN}

Saat ini, wacana mengenai kelompok LGBT dalam media arus utama Indonesia masih sangatlah heteronormatif dan bias-agama. Wacana tersebut didukung oleh representasi kelompok LGBT di media yang kerap kali negatif. Kelompok LGBT banyak direpresentasikan sebagai kumpulan orang-orang yang memiliki penyimpangan secara psikologis dan merupakan penyakit masyarakat 
(Nugroho, dkk., 2013). Selain itu, kelompok LGBT juga cenderung dieksploitasi keberadaannya untuk membuat pemberitaan di media arus utama lebih sensasional. (Nugroho, dkk., 2013).

Pemberitaan sensasional dengan memanfaatkan identitas kelompok LGBT dilakukan untuk meningkatkan rating (atau dalam media daring disebut clickbait). Clickbait memiliki prinsip yang serupa dengan rating yakni mengukur banyaknya khalayak audiens atau pembaca. Dengan membuat berita yang sensasional, media dapat meraup banyak khalayak yang berpotensi dalam mempertahankan ekonomi media. Hal tersebut sesuai dengan pernyataan McQuail (2010) bahwa khalayak, sebagai kumpulan dari konsumen nyata ataupun potensial, merupakan penentu rating suatu media massa.

Pemberitaan sensasional berpotensi menciptakan suatu ketidaksetaraan sosial. Dalam hal ini, media arus utama berperan dalam memproduksi ketidaksetaraan sosial yang membuat kelompok subordinat tidak dapat melakukan apa-apa selain terus menjadi objek komodifikasi (Griffin, Ledbetter, \& Sparks, 2015). Hingga kini, kelompok LGBT lebih banyak menjadi konsumen berita yang tidak memiliki kuasa atas pemberitaan mengenai dirinya (Nugroho, dkk., 2013). Tak ayal, wacana yang berkembang mengenai kelompok LGBT hanya dikuasai oleh kelompok-kelompok dominan.

Media arus utama yang pada dasarnya dibuat untuk melanggengkan ideologi dominan melalui wacana yang dilemparkannya (Griffin, Ledbetter \& Sparks, 2015). Selain itu, media juga dimanfaatkan oleh kelompok elit untuk melanggengkan kekuasaannya atas kelompok yang disubordinasi. Oleh sebab itu, kelompok LGBT hampir tidak memiliki ruang di dalam media arus utama. Kelompok LGBT, sebagai kelompok minoritas, jarang sekali diberitakan, kecuali ketika salah satu anggota kelompok tersebut melakukan penyimpangan (Shoemaker \& Reese, 1996). 
Tentu saja, wacana mengenai kelompok LGBT yang negatif berdampak pada representasi mental terhadap kelompok LGBT. Selain berperan besar dalam mengontrol pikiran (tingkah laku, norma, ideologi, pengetahuan, nilai, dan niat) khalayak, wacana dalam media juga berperan dalam mempengaruhi tindakan khalayak berdasarkan representasi mental tersebut (van Dijk, 2011). Banyaknya pemberitaan mengenai kelompok LGBT yang cenderung disensasionalkan oleh media arus utama menimbulkan anggapan negatif terhadap kelompok LGBT di tengah-tengah masyarakat. Anggapan negatif terhadap kelompok LGBT tentu saja memiliki andil dalam meningkatkan diskriminasi dan juga kekerasan terhadap kelompok LGBT di Indonesia.

Berbagai kekerasan secara fisik maupun sosial yang ditujukan untuk kelompok LGBT sepanjang Juni hingga September 2016 dan hal tersebut disebabkan oleh pemberitaan dalam media (Human Rights Watch, 2016). Pemberitaan negatif mengenai kelompok LGBT dalam media juga meningkatkan ketegangan di ranah publik dan privat yang berujung pada hilangnya akses informasi dan berekspresi bagi kelompok LGBT di Indonesia (Human Rights Watch, 2016).

Di tengah-tengah hegemoni media arus utama yang mewacanakan kelompok LGBT secara negatif, terdapat beberapa media lain yang berusaha menawarkan alternatif dalam mewacanakan kelompok LGBT. Salah satu media tersebut ialah Magdalene. Magdalene merupakan publikasi daring yang dirilis oleh Devi Asmarani, Hera Diani, dan Karima Anjani pada 26 September 2013. Tujuan awal media ini ialah untuk merepresentasikan suara-suara perempuan yang jarang ditemukan dalam media perempuan arus utama.

Magdalene banyak merilis publikasi terkait isu-isu gender dan seksualitas, agama, politik dan budaya, yang secara khusus dijadikan sarana untuk menyuarakan kelompok-kelompok yang termarginalkan, tersubordinasi, terdiskriminasi, dan terstigma. Hal tersebut membuat Magdalane 
tidak hanya berfokus pada isu perempuan saja, melainkan juga isu lain seperti pluralisme, pemberdayaan, toleransi, hingga Lesbian, Gay, Biseksual, dan Transgender (LGBT).

Magdalene mempublikasikan artikel berupa berita atau opini mengenai kelompok LGBT. Konsistensi Magdalene dalam menyuarakan wacana mengenai kelompok LGBT terlihat sejak Januari 2014. Hingga kini, sudah ada 65 publikasi yang secara khusus membahas mengenai kelompok LGBT baik dari segi politik, sosial, budaya, maupun agama. Magdalene secara terbuka menerima kontribusi dari kontributor lepas tanpa memandang ras, gender, agama, suku, orientasi seksual, dan identitas lainnya.

Kemunculan Magdalene sebagai media yang menawarkan interpretasi alternatif terhadap kelompok LGBT sangat menarik mengingat Magdalene pada dasarnya merupakan media feminis, bukan media yang secara khusus diperuntukkan untuk kelompok LGBT. Tentu saja keputusan Magdalene untuk membawa wacana mengenai kelompok LGBT dilator-belakangi oleh berbagai faktor, salah satunya ialah faktor produksi teks dalam media tersebut.

Sebagaimana Fairclough mengatakan bahwa suatu wacana tidak hanya terbatas pada proses mikro secara tekstual saja (Eriyanto, 2001), wacana mengenai kelompok LGBT yang dipublikasikan Magdalane tentu juga dipengaruhi oleh faktor produksi teks atau biasa disebut dengan praktik wacana. Praktik wacana meliputi rutinitas media, hubungan antar anggota redaksi, pertimbangan yang dimiliki jurnalis dalam menerbitkan publikasi, dan juga latar belakang individu sebagai jurnalis. Seluruh aspek tersebut diyakini dapat mempengaruhi isi publikasi suatu media.

Berdasarkan penjabaran di atas, peneliti tertarik untuk mengetahui lebih lanjut bagaimana sebuah media feminis dapat secara terbuka menyuarakan wacana mengenai kelompok LGBT. Dalam melakukan analisis, peneliti menggunakan metode analisis wacana kritis yang dikembangkan oleh 
Norman Fairclough, khususnya mengenai analisis praktik wacana. Selain itu, peneliti juga menggunakan teori hierarki pengaruh isi media yang digagas oleh Reese \& Shoemaker (1996, 2016) untuk mengungkap bagaimana praktik wacana dalam Magdalene mempengaruhi konten publikasi yang telah diterbitkannya.

\section{TINJAUAN PUSTAKA}

\section{HIERARKI PENGARUH ISI MEDIA}

Penelitian ini didasari oleh teori hierarki pengaruh isi media dalam era media baru yang dikembangkan oleh Reese \& Shoemaker (2016). Dalam teori ini, terdapat beberapa asumsi mengenai faktor-faktor yang mempengaruhi isi media, di antaranya ialah individu, rutinitas media, organisasi media, institusi sosial, dan sistem sosial dalam masyarakat.

Dalam penelitian ini, peneliti berfokus pada faktor individual yang mempengaruhi konten isi media. Peneliti akan melakukan analisis berdasarkan asumsi yang dikembangkan oleh Reese \& Shoemaker $(1996,2016)$ bahwa konten media diproduksi sebagai efek lanjut dari perilaku, kepercayaan, dan nilai-nilai yang dianut. Perilaku, kepercayaan, dan nilai-nilai tersebut dipengaruhi oleh pengalaman, karakteristik (gender, etnis, orientasi seksual, dsb), dan latar belakang individu seperti pendidikan, kondisi sosial dan ekonomi keluarga, agama, dsb (Reese \& Shoemaker, 1996).

Selain berfokus pada faktor individual, peneliti juga berfokus pada faktor lain seperti rutinitas media. Rutinitas media meliputi segala aspek, salah satunya ialah nilai-nilai berita. Menurut Reese \& Shoemaker $(1996,2016)$, selain mencakup hal-hal yang dinilai penting, tidak biasa, dan kontroversial, pemberitaan saat ini juga cenderung mengangkat nilai-nilai yang populer, dibagikan, dan mudah disebar-luaskan. 


\section{METODOLOGI}

Metode yang digunakan dalam penelitian ini ialah metode penelitian kualitatif. Selain itu, peneliti melakukan wawancara mendalam dengan aktor-aktor yang terlibat dalam proses produksi teks mengenai kelompok LGBT dalam Magdalene untuk pengumpulan data.

Untuk mendapatkan informan yang sesuai dengan penelitian yang diteliti, maka peneliti menggunakan teknik penentuan informan yakni dengan menggunakan teknik purposive sampling. Menurut Sugiyono (2010:53), purposive sampling adalah teknik pengambilan sampel sumber data dengan pertimbangan tertentu. Pertimbangan tertentu memiliki maksud, semisal orang tersebut dianggap paling tahu tentang apa yang diharapkan.

Informan dari penelitian ini merupakan angota redaksi dari Magdalene. Anggota dan pemimpin redaksi Magdalene dipilih karena mereka merupakan pihak yang terlibat dalam penyebarluasan wacana LGBT (Lesbian, Gay, Biseksual, Transgender) selama proses produksi teks berlangsung. Informan tersebut ialah Devi Asmarani selaku kepala redaksi, Hera Diani selaku redaktur pelaksana, dan Ayunda Nurvitasari selaku reporter.

Analisis data dalam penelitian ini dilakukan dengan menggunakan model analisis praktik wacana yang dikembangkan Fairclough (Eriyanto, 2001) Analisis ini dilakukan untuk mengetahui bagaimana rutinitas media, pertimbangan yang dimiliki jurnalis dalam menerbitkan publikasi, dan juga faktor individu jurnalis itu sendiri mempengaruhi wacana yang dibawa. 


\section{HASIL PENELITIAN}

\section{GAMBARAN UMUM MAGDALENE}

Magdalene merupakan publikasi daring yang berdiri pada September 2013. Misi yang dimiliki Magdalene ialah untuk merepresentasikan wacana mengenai perempuan yang jarang ditemukan dalam media perempuan kebanyakan (Asmarani, dalam wawancara, 16 Maret 2018). Selain berfokus ada isu perempuan, Magdalene juga berfokus pada isu interseksionalitas (Asmarani, dalam wawancara, 16 Maret 2018). Hal tersebut menjadi alasan mengapa banyak publikasi Magdalene yang bersinggungan dengan identitas minoritas lain seperti kelas, kewarganegaraan, ras, etnis, gender, ataupun seksualitas.

Keyakinan bahwa penindasan dapat berulang dan saling tumpang tindih karena identitas minoritas lain yang dimiliki perempuan seperti kewarganegaraan, ras, etnis, kelas hingga seksualitas menjadi latar belakang mengapa isu interseksionalitas banyak muncul dalam media-media feminis (Zack, 2005:7; Nash, 2008:10). Interseksionalitas sendiri merupakan konsep yang dicetuskan oleh feminis kulit hitam dengan asumsi bahwa feminisme saat ini tidaklah inklusif, sebab hanya berkaca pada pengalaman feminis kulit putih (Okolosie, 2014). Hal tersebut menyebabkan publikasi dalam Magdalene banyak memuat isu-isu terkait pemberdayaan, toleransi, pluralisme, hingga LGBT. Dalam wawancara dengan peneliti, Devi mengatakan bahwa Magdalene membawa isu-isu LGBT karena LGBT termasuk dalam isu-isu interseksionalitas (Asmarani, 2018).

Pada awal peluncurannya, Magdalene sepenuhnya menggunakan bahasa inggris dengan alasan bahw pendirinya lebih familiar dengan bahasa inggris sepanjang karir jurnalistiknya. Selain itu, Magdalene juga ingin mencapai target pembaca secara internasional (Asmarani, 2018). Beberapa tulisan di Magdalene juga diterbitkan di Filipina melalui Rappler Philippines (Asmarani, 2018). 
Akan tetapi, menurut Devi, dalam wawancara pada 16 Maret 2018, pada akhirnya Magdalene memutuskan untuk menerbitkan edisi bahasa Indonesia.

Meningkatnya permintaan edisi berbahasa Indonesia dari pembaca membuat Magdalene banyak memproduksi dan menerjemahkan artikel berbahasa inggris yang ada. Selain itu, pembaca Magdalene yang 95\% berada di Indonesia juga menjadikan alasan media tersebut meningkatkan produksi teks berbahasa Indonesia.

Hingga kini Magdalene masih terus mempublikasikan artikel berupa berita dan opini yang banyak disebarluaskan melalui akun media sosial yang dikelolanya. Publikasi yang banyak menyedot perhatian pembaca sampai saat ini ialah publikasi seputar spiritualitas, agama, dan gender, termasuk LGBT (Diani, 2018).

\section{RUTINITAS MEDIA}

Menurut Devi, dalam proses produksi teks sendiri, tim editorial terdiri dari dirinya, Hera Diani sebagai managing editor, Ayunda Nurvitasari sebagai reporter, dan juga dua orang reporter magang lainnya yang masih duduk di bangku kuliah (Asmarani, 2018). Di samping menerima publikasi secara berkala melalui kontributor lepas, Magdalene juga memuat publikasi yang ditulis langsung oleh redaksi Magdalene (Asmarani, dalam wawancara, 16 Maret 2018). Jumlah artikel

yang ditulis langsung oleh pihak redaksi minimal berjumlah tiga buah setiap bulannya. Rapat redaksi dilaksanakan minimal satu bulan sekali dan membahas mengenai arah Magdalene ke depan secara berkelanjutan. Meskipun begitu, setiap minggunya juga ada koordinasi via whatsapp mengenai tema mingguan yang akan dipublikasikan Magdalene (Asmarani, 2018).

Redaktur biasanya memberi instruksi langsung kepada reporter terkait tema publikasi yang harus ditulis. Tetapi terkadang, dalam beberapa kasus, reporter pun diminta untuk menulis publikasi 
dengan judul, sudut pandang dan tema yang dipilih sendiri. Menurut Ayunda Nurvitasari selaku reporter, biasanya ia sebagai reporter diinstruksikan untuk meliput kegiatan tertentu dan menulisnya sesuai dengan nilai-nilai yang diangkat Magdalene. Selain itu, ia juga memaparkan bahwa redaktur seringkali menginstruksikan dirinya untuk menulis publikasi seperti reportase ataupun opini dengan tema yang sekiranya ia sukai (Nurvitasari, 2018).

\section{INDIVIDU DAN PROFESI JURNALIS}

Meminjam istilah yang diperkenalkan oleh Gramsci (West \& Turner, 2014), Magdalene merupakan dapat dikatakan sebagai "counter-hegemony" dengan usahanya menentang ideologi dominan dalam media arus utama yang cenderung meminggirkan kelompok LGBT. Magdalene sendiri digerakkan oleh orang-orang yang menganut ideologi feminis, baik editor hingga reporter. Sebagai seorang feminis, penting sekali untuk sadar terhadap isu-isu interseksionalitas. Baik Devi dan Hera sebagai editor, ataupun Ayunda sebagai reporter, meyakini bahwa feminisme akan selalu berkaitan dengan isu-isu interseksionalitas.

Adanya isu interseksionalitas di tengah-tengah publikasi feminis dilatar-belakangi oleh keyakinan bahwa penindasan dapat berulang dan saling tumpang tindih karena identitas minoritas lain yang dimiliki perempuan seperti ras, kelas kewarganegaraan, etnis hingga seksualitas (Zack, 2005; Nash, 2008). Interseksionalitas sendiri merupakan konsep yang dikembangkan oleh feminis kulit hitam dengan berangkat dari keyakinan bahwa feminisme yang berkembang saat ini terlalu fokus pada pengalaman feminis kulit putih dan tidak inklusif (Okolosie, 2014:90).

Selain keyakinan bahwa feminisme selalu bersinggungan dengan isu-isu interseksionalitas, adanya kepedulian yang besar atas Hak Asasi Manusia (HAM) juga membuat para penggerak Magdalene banyak membawa wacana terkait kelompok LGBT yang berbeda dengan wacana dominan. Baik 
Hera, Devi maupun Ayunda sama-sama meyakini bahwa selayaknya manusia biasa, kelompok LGBT juga memiliki potensi dan hak hidup. Mereka pun juga meyakini bahwa perlu sekali mengangkat wacana alernatif terkait kelompok LGBT agar diskriminasi terhadap kelompok tersebut dapat berkurang.

Reese \& Shoemaker (1996) mengungkapkan bahwa perilaku, nilai, dan kepercayaan yang dimiliki individu jurnalis dipengaruhi oleh karakteristik, latar belakang, serta pengalaman yang dimilikinya. Lebih lanjut lagi, perilaku, nilai, dan kepercayaan yang dianut membentuk sikap professional dan juga konten media yang diproduksi. Berdasarkan pernyataan tersebut dapat dilihat bahwa pandangan terhadap isu-isu interseksionalitas dan Hak Asasi Manusia (HAM) yang mempengaruhi konten dalam Magdalene secara garis besar dipengaruhi oleh latar belakang pendidikan dan kepribadian masing-masing individu jurnalis yang memproduksinya.

Kepribadian serta pendidikan yang ditempuh Devi memberikan pengaruh signifikan terhadap pandangannya mengenai kelompok LGBT (Asmarani, 2018). Menurutnya, ia sudah mulai berani mempertanyakan konstruksi gender dan budaya yang menempatkannya secara tidak adil sejak kecil (Asmarani, 2018). Di samping itu, pendidikan yang ia tempuh di Amerika Serikat sedari bangku sekolah hingga kuliah di jurusan jurnalistik, juga memiliki andil besar dalam menjadikannya seorang feminis yang terbuka pada isu-isu interseksionalitas (Asmarani, 2018).

Serupa dengan Devi, Ayunda pun menyatakan bahwa latar belakang pendidikannya juga memiliki andil dalam membuatnya menjadi seorang feminis. Latar belakang pendidikannya dalam kajian budaya membentuk pandangannya terhadap kelompok LGBT menjadi lebih terbuka. Ayunda menuturkan bahwa melalui kelas dan diskusi dalam perkuliahan ia mulai banyak belajar menganai sejarah gender dan seksualitas (Nurvitasari, 2018). 
Sedangkan bagi Hera, latar belakang keluarganya yang selalu memberikannya kebebasan untuk menentukan pilihan membuatnya terbuka terhadap isu-isu kesetaraan dan perempuan. Selain itu, pendidikannya yang ditempuh di institusi katolik membuatnya terbuka pada keberagaman, dan berlanjut pada isu-isu feminis dan interseksionalitas (Diani, 2018).

Pandangan penggerak Magdalane yang dipengaruhi oleh latar belakang masing-masing individu memberikan pengaruh terhadap wacana mengenai kelompok LGBT yang ada di media tersebut. Hal tersebut membenarkan teori yang digagas oleh Reese \& Shoemaker (1996:61) bahwa karakteristik, pengalaman dan latar belakang individu mempengaruhi nilai dan kepercayaan yang dianut, serta kepercayaan itu nantinya mempengaruhi konten media yang diproduksinya.

\section{KRITERIA PUBLIKASI}

Menurut Reese \& Shoemaker (1996), tidak semua konten yang ada dapat memenuhi standar media. Selalu ada proses seleksi ide-ide yang hendak diberitakan berdasarkan standar tertentu. Serupa dengan pernyataan yang dikemukakan Reese \& Shoemaker (1996), Magdalene memiliki kriteria publikasi yang menjadi acuan dalam proses seleksi konten berita.

Magdalene memiliki standar penulisan seperti majalah yang membedakannya dengan blog biasa. Selain itu, Magdalene juga hanya mempublikasi tulisan yang sesuai dengan nilai-nilai yang didukungnya. Tulisan yang akan dipublikasi hendaknya tidak mengandung kebencian, dan memperparah stigmatisasi terhadap kelompok tertentu (Asmarani, 16 Maret 2018).

Selain memiliki standar yang tidak serupa dengan blog, publikasi dalam harus memuat nilai-nilai interseksionalitas. Hal tersebut sejalan dengan tujuan Magdalene yakni menyuarakan wacana interseksionalitas yang mendukung hak-hak kelompok minoritas yang termarginalkan, 
terdiskriminasi, terstigma, dan tersubordinasi seperti kelompok minoritas keagamaan, etnis, ras, hingga gender dan seksualitas atau familiar dengan sebutan kelompok LGBT (Asmarani, 2018).

Ayunda Nurvitasari selaku reporter yang banyak menulis publikasi terkait LGBT juga mengungkapkan pendapat serupa. Menurutnya, hal-hal yang diperjuangkan feminisme pasti akan selalu bersinggungan dengan isu kelompok marginal lain, sebab kelompok marginal lainnya samasama mengalami diskriminasi seperti perempuan (Nurvitasari, 2018). Berdasarkan pernyataan dari Devi (Asmarani, 2018) dan Ayunda (Nurvitasari, 2018), tak heran apabila hingga kini, publikasi yang ada di Magdalene juga berfokus pada isu-isu LGBT, sebab isu-isu progresif tersebut merupakan bagian dari kajian interseksionalitas dan feminisme.

Adanya standar penulisan yang lebih condong menyerupai majalah daripada blog, serta kriteria yang membawa nilai-nilai yang dianut Magdalene membernarkan asumsi yang dikembangkan oleh Reese \& Shoemaker (1996) bahwa kriteria tulisan yang ditetapkan oleh suatu media mempengaruhi konten media yang dipublikasikan. Kriteria tersebut selain menyangkut format penulisan, juga menyangkut nilai-nilai yang diangkat sebuah media, yang apabila ditarik lebih jauh juga dipengaruhi oleh individu pendiri dan penggeraknya. Dapat dilihat bahwa konten-konten dalam Magdalene dipublikasikan dengan berlandaskan kriteria publikasi yang telah ditetapkan sebelumnya oleh pihak redaksi.

\section{DISKUSI}

Dalam membahas mengenai pengaruh individu terhadap konten media, Reese \& Shoemaker (1996) memberikan beberapa poin yang menjadi latar belakang individu sebagai seorang jurnalis seperti gender, etnis, orientasi seksual, kondisi ekonomi, dan juga pendidikan. Dalam level analisis individu, bagaimana individu terbentuk, mengambil peran, dan identitas dengan sekelilingnya 
menjadi pertimbangan dalam melakukan analisis level mikro terhadap individu sebagai jurnalis (Reese \& Shoemaker, 2016). Para penggerak Magdalene sendiri datang dari latar belakang yang hampir serupa terutama ketika berbicara mengenai gender, kondisi ekonomi, dan juga pendidikan.

Berdasarkan hasil penelitian, dapat diketahui bahwa Devi, Hera, maupun Ayunda merupakan perempuan yang sama-sama memiliki pandangan bahwa gender bersifat non biner sehingga mereka banyak menuangkan gagasannya melalui konten-konten Magdalene. Selain itu, baik Devi, Hera, maupun Ayunda datang dari kelaurga yang memiliki privilese untuk menempuh pendidikan di institusi pendidikan tinggi sehingga mereka dapat terpapar isu-isu feminis dan interseksionalitas selama kuliah. Latar belakang tersebutlah yang menurut Reese \& Shoemaker (1996, 2016) memberikan pengaruh pada nilai, perilaku, dan kepercayaan yang dianut oleh individu sebagai jurnalis.

Ketika berbicara mengenai nilai, perilaku, dan kepercayaan yang dianut individu sebagai jurnalis, Reese \& Shoemaker (1996) menjabarkan beberapa poin yakni nilai dan kepercayaan personal, pandangan politik personal, dan orientasi keagamaan. Poin mengenai nilai, perilaku, dan kepercayaan individu, seperti halnya poin sebelum yakni latar belakang, memang memiliki pengaruh yang tidak terlalu terlihat. Walaupun begitu, ternyata poin ini memiliki pengaruh besar dalam mempengaruhi konten media (Reese \& Shoemaker, 1996).

Berdasarkan hasil penelitian, dapat diketahui bahwa dari ketiga poin terkait nilai dan kepercayaan personal, pengaruh orientasi keagamaan masing-masing individu sebagai jurnalis memiliki peran sentral bagi para penggerak Magdalene. Baik Ayunda dan Hera, dalam wawancara bersama peneliti, mengungkapkan keresahannya mengenai perkembangan fundamentalisme islam di Indonesia. Keduanya memiliki keyakinan bahwa tafsir keislaman seharusnya berkembang kea rah yang lebih moderat dan inklusif. Sedangkan Devi, secara terang-terangan, menyatakan bahwa 
dirinya tidak terkait dengan agama apapun, sehingga ia banyak berfokus pada isu-isu interseksionalitas dan pluralisme. Meskipun begitu, Devi tetap berharap bahwa agama di Indonesia dapat berkembang kea rah yang lebih terbuka. Pandangan para penggeraknya yang liberal membuat Magdalene dapat secara terbuka terhadap isu-isu feminism dan interseksionalitas terutama isu-isu mengenai kelompok LGBT.

Latar belakang individu yang mempengaruhi nilai, perilaku dan kepercayaan juga lebih lanjut lagi akan mempengaruhi etika professional individu sebagai jurnalis. Menurut Reese \& Shoemaker (1996), bagaimana jurnalis memposisikan dirinya sebagai pekerja professional dipengaruhi oleh nilai, perilaku, dan kepercayaan yang dimiliki. Individu jurnalis dapat memposisikan dirinya sebagai pihak yang netral dan dapat juga memiliki keberpihakan. Ketika berbicara mengenai Magdalene, dapat dilihat bahwa masing-masing anggota redaksi Magdalene memposisikan dirinya sebagai aktor yang berpihak dalam menyuarakan suara-suara kelompok marginal ataupun minoritas yang terseubordinasi dan terdiskriminasi (Asmarani, 2018).

\section{KESIMPULAN}

Wacana mengenai kelompok LGBT yang dibawa Magdalene banyak dipengaruhi oleh ideologi feminis yang dianut para penggeraknya. Para penggerak Magdalene juga meyakini isu-isu hak asasi manusia dan inerseksionalitas yang selalu bersinggungan dengan feminisme. Sehingga tak heran bahwa Magdalene banyak masuk ke dalam isu-isu interseksionalitas seperti LGBT.

Para penggerak Magdalene juga memiliki pandangan yang terbuka terhadap isu LGBT dan mendukung keberadaan kelompok LGBT. Mereka menganggap bahwa LGBT hanya bagian dari dinamika keberagaman gender dan seksualitas, dan mereka hanyalah manusia biasa seperti yang lainnya. Temuan dalam penelitian ini menunjukkan bahwa pandangan yang dimiliki individu 
penggerak Magdalene sebagai jurnalis mempengaruhi praktik wacana yang ada dalam suatu media. Selain itu, bagaimana parang anggota redaksi memposisikan dirinya sebagai pihak yang melakukan advokasi terhadap kelompok LGBT sebagai kelompok minoritas yang termarginalkan, terstigma, dan terdiskriminasi juga mempengaruhi konten dalam publikasi Magdalene.

Di samping itu, adanya standar penulisan dengan kriteria yang membawa nilai-nilai yang dianut juga menjawab mengapa Magdalene membawa wacana mengenai kelompok LGBT dengan cara

yang berlawanan dengan media arus urama. Kriteria tersebut ialah membawa nilai-nilai feminis dan interseksionalitas. Selain itu, publikasi di Magdalene juga tidak boleh mengandung ujaran kebencian, dan memperparah stigmatisasi terhadap kelompok tertentu

\section{REFERENSI}

Eriyanto. (2001). Analisis Wacana: Pengantar Analisis Teks Media, Yogyakarta: LKIS.

Griffin, Em, Ledbetter, Andrew \& Sparks, Glenn. 2015. A First Look at Communication Theory (ninth ed.), New York: McGraw-Hill Education.

McQuail, Denis. (2010). McQuail's Mass Communication Theory (sixth ed.), Singapore: SAGE Publications Asia-Pacific Pte Ltd.

Nash, Jennifer C. (2008). "Re-Thinking Intersectionality" Feminist Review, 89, 1-15. DOI http://dx.doi.org/10.1057/fr.2008.4.

Nugroho, dkk. (2013). Media and the Vulnerable in Indonesia: Accounts from the Margins, Jakarta: Centre for Innovation Policy and Governance.

Okolosie, Lola. (2014). "Beyond 'Talking' and 'Owning' Intersectionality" Feminist Review, 108, 90-96. DOI http://dx.doi.org/10.1057/fr.2014.14.

Shoemaker, Pamela J. \& Reese, Stephen D. (1996). Mediating the Message: Theories of Influences on Mass Media Content, (second ed), New York: Longman Publishers USA.

Shoemaker, Pamela J. \& Reese, Stephen D. (2016). "A Media Sociology for the Networked Public Sphere: The Hierarchy of Influences Model" Mass Communication and Society, 19, 389410. DOI: $10.1080 / 15205436.2016 .1174268$

Sugiyono. (2007). Metode Penelitian Kuantitatif-Kualitatif dan R\&D, Bandung: Alfabeta.

Van Dijk, Teun. A. (2011). Discourse Studies: A Multidisciplinary Introduction (second ed.), London: Sage Publications Ltd. 
Watch, Human Rights. (2016). "Permainan Politik ini Menghancurkan Hidup Kami” Komunitas LGBT Indonesia Dalam Ancaman, New York : HRW

West, Richard \& Turner, Lynn H. (2014). Introducing Communication Theory: Analysis and Application (fifth ed.), New York: McGraw-Hill Education. 